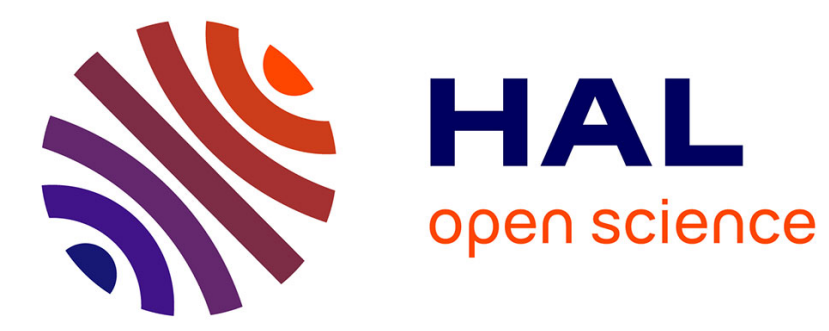

\title{
Species transfer via topsoil translocation: lessons from two large Mediterranean restoration projects
}

Elise Buisson, Renaud Jaunatre, Christine Romermann, Adeline Bulot, Thierry Dutoit

\section{- To cite this version:}

Elise Buisson, Renaud Jaunatre, Christine Romermann, Adeline Bulot, Thierry Dutoit. Species transfer via topsoil translocation: lessons from two large Mediterranean restoration projects. Restoration Ecology, 2018, SEED DISPERSAL AND SOIL SEED BANKS - PROMISING SOURCES FOR ECOLOGICAL RESTORATION, 26 (S2), pp.S179 - S188. 10.1111/rec.12682 hal-01883767

\section{HAL Id: hal-01883767}

\section{https://institut-agro-rennes-angers.hal.science/hal-01883767}

Submitted on 3 Dec 2018

HAL is a multi-disciplinary open access archive for the deposit and dissemination of scientific research documents, whether they are published or not. The documents may come from teaching and research institutions in France or abroad, or from public or private research centers.
L'archive ouverte pluridisciplinaire HAL, est destinée au dépôt et à la diffusion de documents scientifiques de niveau recherche, publiés ou non, émanant des établissements d'enseignement et de recherche français ou étrangers, des laboratoires publics ou privés. 


\section{Species transfer via topsoil translocation: lessons from two large Mediterranean restoration projects}

3

4

5

6

7

8

9 10

21

\section{2 * Corresponding author: elise.buisson@univ-avignon.fr}

23

24

25

26

27

28

29

30

\section{Running head: Mediterranean grassland topsoil translocation} Martin d'Hères. University Jena, D-07743 Jena, Germany 04103, Leipzig, Germany cedex 01, France

4

5 Author contributions 9 the manuscript.

Elise Buisson ${ }^{1}$, Renaud Jaunatre ${ }^{2}$, Christine Römermann $^{3,4}$, Adeline Bulot $^{5}$, Thierry Dutoit ${ }^{1}$

1. IMBE, Université d'Avignon et des Pays de Vaucluse, CNRS, IRD, Aix Marseille Université, IUT d'Avignon, Agroparc BP 12607, 84911 Avignon cedex 9.

2. Université Grenoble Alpes, Irstea, UR EMGR. 2 rue de la Papeterie, 38400 Saint

3. Institute of Ecology and Evolution, Dpt. Plant Biodiversity, Friedrich Schiller

4. German Centre for Integrative Biodiversity Research (iDiv) Halle-Jena-Leipzig, D-

5. Agrocampus Ouest Angers, UMR BAGAP, 2 rue André Le Nôtre, F-49045 Angers

2 EB identified the article content, wrote the first version of the article and managed the 27 manuscript preparation; all coauthors collected the data; RJ analyzed the data, produced all 8 figures and participated in writing the discussion; all coauthors edited the various versions of 
34 Restoration success of species-rich grasslands is often limited by low seed dispersal. To

35 reintroduce target species of local provenances, bulk topsoil transfer is performed by excavating soil and vegetation from donor sites and spreading these on receptor sites. Our first objective was to determine the most advantageous season for transferring topsoil in Mediterranean grasslands. The second objective was to assess which treatment - combination of season (spring or autumn) and transfer ratio (1:1 or 1:3) - performed best in restoring a Mediterranean grassland through bulk topsoil transfer after two large restoration projects. Just-in-time soil transfer (i.e. with no stockpiling) was implemented 1) on a former 3-ha orchard where topsoil was spread after removing trees and levelling soil, and 2) after a 5-ha oil pipeline leak where polluted soil was removed prior to treatment (soil horizons were reconstituted). A seed bank study showed that the summer seed bank contained higher seed densities, species richness and similarity to the reference site than the spring seed bank. Spring transfers gave better results than autumn transfers in terms of species richness and composition similarity with the reference site, while transfer ratios gave similar results. Longterm success was not driven by season or transfer ratio but by the underlying seed bank at receptor sites: the former orchard's weed-containing seed bank hampered topsoil transfer success. This study also suggests that restoration success cannot be deduced from seed bank studies alone, as species establishment is highly dependent on differences in growing conditions (including competition at receptor sites).

Keywords: bulk topsoil transfer; sod dumping; soil inoculation; seed bank; steppe 


\section{8}

\section{Implications for practice}

- Mediterranean grassland summer seed bank (vs. spring seed bank) contains higher seed densities and species richness, indicating that summer is better than spring for transferring seed banks of Mediterranean grasslands; using spring topsoil transfer (vs. autumn transfer) to restore Mediterranean grasslands gives better results in terms of species richness and composition similarity with the reference site (summer transfer could not be tested here);

- Topsoil transfer success is not greatly impacted by transfer ratio: the tested ratios 1:1 and 1:3 yield identical species richness and composition similarity with the reference Mediterranean grassland;

- The underlying seed bank at the receptor sites is an important factor in long-term topsoil transfer success to restore Mediterranean grasslands.

\section{Introduction}

The restoration of species-rich grasslands is often limited by low seed dispersal (Buisson et al. 2006; Grman et al. 2015; Halassy et al. 2016), both in space and time (e.g. Römermann et al. 2005). Successful methods of reintroducing target species of local provenances commonly include sowing seed mixtures and transferring seed-containing hay or soil (Kiehl et al. 2010). Soil transfer can be accomplished through i) turf transfer, also called community translocation, or ii) bulk topsoil transfer, also called sod dumping (Bullock 1998; Kiehl et al. 2010; Jaunatre 2014a; Bulot et al. 2014, 2017). Soil transfer means that not only seeds are transferred, but also other propagules such as rhizomes, small shallow-rooted plants, and micro-organisms that may play an important role in the restoration of the plant community (Török et al. 2011; Wubs et al. 2016). Of the two techniques, bulk topsoil transfer is the cheapest (Good et al. 1999), especially if soil is spread at a ratio lower than 1:1, i.e. spread on an area larger than where it was gathered (e.g. ratio of 1:2, Good et al. 1999; ratio of 1:3, Jaunatre et al. 2014a).

While both soil transfer techniques are based on extracting soil from donor sites scheduled to be destroyed and thus are not sustainable, they are fundamentally different. Turf transfer consists in cutting and transferring turfs and mainly relies on the survival and colonization potential of the plants contained in the turfs (Bullock 1998; Kardol et al. 2009; 
Vécrin \& Muller 2003). Bulk topsoil transfer, the type explored in this study, consists in excavating soil and vegetation from donor sites and spreading these on receptor sites, often at a ratio of 1:1 (see Kiehl et al. 2010 for review); it relies mainly on the availability of viable soil-stored seeds and other propagules.

Prior to large-scale bulk topsoil transfer, seed bank studies are often carried out at the donor sites. First, restorationists need to evaluate the potential of implementing such a technique: topsoil transfer is worth implementing only if the topsoil contains seeds of target species, particularly in regions where seeds are not available commercially (Fowler et al. 2015). Using soil seed banks as a source of material for restoration of various plant communities (forests, marshes, grasslands, heathlands) has been widely explored via seed bank studies (e.g. the review by Bossuyt \& Honnay 2008 of 102 studies and the case study by Kalamees et al. 2012). With the exception of some grasslands, heathlands and early successional communities, these 103 seed bank studies concluded that restoration cannot rely solely on seed banks. However, bulk topsoil transfer is still used in many countries and for the restoration of various types of ecosystems, such as roadsides, meadows, grasslands, forests, etc., with relative success (Kiehl et al. 2010; Fowler et al. 2015). While this discrepancy between the findings of seed bank studies and the continuing practice of bulk topsoil transfer (Fowler et al. 2015) remains insufficiently studied, both bulk topsoil transfer and seed bank studies continue to be performed.

The second reason for performing seed bank studies prior to large-scale bulk topsoil transfer is to determine the most advantageous time for transfer. Ideally, transfer should be carried out at a season when a maximum proportion of the target species are found as seeds in the soil (De Villiers et al. 2004; Hosogi \& Kameyama 2004), typically at the end of the vegetation period and, in the Mediterranean region, before the onset of the autumn rainy season (Grillas et al. 2004; De Villiers et al. 2004). This is particularly important when aiming to restore plant communities containing many species with a transient seed bank (Buisson et al. 2006). The third objective of prior seed bank studies is to permit subsequent evaluation of restoration success. After topsoil transfer, monitoring is carried out to document vegetation establishment on the receptor sites; the composition of the vegetation is often compared with the seed bank and vegetation of the donor sites to evaluate restoration success (Vécrin \& Muller 2003). 
The objectives of this study are 1) using a seed bank study, to assess whether spring or summer is more advantageous for transferring topsoil to restore Mediterranean grasslands and 2) using a topsoil transfer experiment, to assess the best combination of season (spring or autumn) and bulk topsoil transfer ratio (1:1 or 1:3 hereafter termed topsoil transfer ratio) to restore a Mediterranean grassland plant community. The best transfer time should be summer, when topsoil contains both species that form a more persistent seed bank and species that form only a transient seed bank; however, this season could not be tested mainly due to constraints inherent to worksites. Soil transfers were implemented in autumn and spring. Our hypotheses are that i) the best transfer time between spring and autumn is spring, when topsoil contains the few species fruiting in late autumn, ii) the best topsoil transfer treatment is at a ratio of 1:1 (delivering a higher number of seeds per area unit).

\section{Methods}

\section{Study sites}

The study sites are situated in south-eastern France, in a pseudo-steppe located in the plain of La Crau which has recently undergone several large restoration projects, three of which included soil transfer. La Crau is the ancient delta of the Durance River, whose dry grassland vegetation once covered 60000 ha. Dominated by perennial species and also including many annual species, this vegetation has been shaped by a dry and windy Mediterranean climate, particular soil conditions (i.e. shallow, relatively poor Haplic Cambisol (Calcaric) soil with silicaceous stones, covering about $50 \%$ of the ground) and many centuries of itinerant sheep grazing (Buisson \& Dutoit 2006; Figure S1). This now fragmented grassland vegetation, of which only 11500 ha remain, serves as a reference ecosystem and donor sites for soil transfers (Jaunatre et al. 2014b). The first restoration site is an area of 357 ha managed from 1987 to 2006 as an orchard, and rehabilitated in 2008 as part of the first mitigation banking experiment launched by the French government (Dutoit et al. 2013). Concurrently with this rehabilitation project, restoration trials were carried out on this orchard: direct topsoil transfer from La Crau dry Mediterranean grassland (with no stockpiling) was implemented on a few hectares in spring and autumn 2009 at ratios of 1:1 or 1:3 (partly described in Jaunatre et al. 2014a; Figure S1). Less than one kilometer away from this former orchard (Figure 1), the grassland soil and vegetation of a 5.5 ha grassland area were completely destroyed by an oil spill due to an underground pipeline leak in 2009 (second site hereafter referred to as pipeline leak site). Restoration consisted in excavating the polluted soil down to the bedrock $(40 \mathrm{~cm})$ 
followed by direct topsoil transfer from La Crau dry Mediterranean grassland, reconstituting soil horizons in spring 2011 (Bulot et al. 2017; Figure S1).

\section{Seed bank study}

To identify the season when the topsoil seed bank of the reference site has the highest seed content, ten replicate $2.5 \mathrm{~L}$ soil samples were taken at the site of Peau de Meau, in the center of the plain of La Crau, in April and August 2001 (Table 1; Römermann et al. 2005). These 20 samples were left to germinate following the protocol described hereafter. Each soil sample taken in the field consisted of 10 pooled subsamples, as recommended by Bakker et al. (1996) taken between 0 and $20 \mathrm{~cm}$ deep using a 4-cm diameter soil corer. The seedling emergence method (Ter Heerdt et al. 1996) was selected to qualify and quantify germinable seeds in the soil seed banks. Soil samples were concentrated by washing them with water on two different sieves ( $2 \mathrm{~mm}$ and $200 \mu \mathrm{m}$ ) to reduce bulk and clay. The concentrated soil was spread in a thin layer $(0.5 \mathrm{~cm})$ on plastic trays filled with $2 \mathrm{~cm}$ vermiculite topped with medical compresses (mesh size about $100 \mu \mathrm{m}$ ). The trays were covered with fine gauze to prevent contamination. All trays were watered frequently from below. Emerged seedlings were identified, counted and removed weekly. Unknown seedlings were grown for identification. After three months of cultivation (greenhouses), the samples were allowed to dry out. Following six weeks of cold stratification $\left(5^{\circ} \mathrm{C}\right)$, the samples were cultivated for a further three months. Vegetation monitoring was carried out in ten replicate $4-\mathrm{m}^{2}$ quadrats in May 2001 (Table 1): we recorded the presence of each species.

\section{Topsoil transfers and vegetation sampling}

Direct topsoil transfer of the 20-cm upper soil layer was implemented on the former orchard in mid-March 2009 at a ratio of 1:3 on 1 ha (Table 1 and 2), and in late October 2009 both at a ratio of $1: 3$ on 3 ha (Jaunatre et al. 2014a) and at a ratio of $1: 1$ on 0.3 ha (Jaunatre et al. 2014a). Direct topsoil transfer was also implemented on the pipeline leak site in spring 2011 at a ratio of 1:1 on 5.5 ha (Table 1 and 2; Bulot et al. 2017). At the former orchard, topsoil was spread over the orchard soil (Jaunatre et al. 2014a). At the pipeline leak site, all soil horizons were reconstituted: i) altered bedrock (35-40 cm deep), ii) subsoil (20-35 cm deep) and iii) topsoil (0-20 cm deep) (Bulot et al. 2017, 2014). Vegetation monitoring was carried out in May 2010, May 2011 and May 2012 on the former orchard and in May 2012, May 2013 and May 2014 on the pipeline leak site. At each site, a minimum of three replicate 4-m² 
quadrats were sampled (Table 1): we recorded the cover of each species and the total percent cover of vegetation using a modified Braun-Blanquet scale (Braun-Blanquet et al. 1952): 0.5 for species covering less than $1 \%$ of the quadrat, 1 for those covering between $1 \%$ and $5 \%, 2$ for those covering between $5 \%$ and $25 \%, 3$ for those covering between $25 \%$ and $50 \%, 4$ for those covering between $50 \%$ and $75 \%$ and 5 for species covering more than $75 \%$ of the quadrat.

\section{Data analysis}

To identify the best time to transfer topsoil to the former orchard and pipeline leak sites, we compared spring and summer seed bank characteristics. Differences in composition between seed banks were assessed using i) species richness and seed density per sample and ii) a redundancy analysis (RDA; matrix: 39 samples $\times 50$ species) based on abundance data from the seed bank, after a Hellinger transformation (Legendre \& Gallagher 2001). Differences in composition between seed banks with above-ground vegetation were assessed using normalized Community Structure Integrity Indices (CSIInorm) calculated on plant species presence / absence data (Jaunatre et al. 2013). To compare means between seasons, GLMs using a Poisson distribution were performed on species richness and seed abundance data as they are count data, and a t-test was performed on CSIInorm as they met parametric conditions.

To compare topsoil transfers implemented to restore Mediterranean dry grassland at the former orchard and pipeline leak sites, and to test the effects of season and transfer ratio (treatments $=$ ratio-season combination) on success, we compared plant species richness and composition between the restored sites. Here again, differences in composition were assessed using i) a normalized Community Structure Integrity Index (CSIInorm) calculated on plant species presence / absence data and ii) a non-metric multidimensional scaling (NMDS; matrix: 33 quadrats $\times 99$ species) based on Bray-Curtis distance calculated from presence / absence data. As species richness data is count data, they were analyzed with a Generalized Linear Model (GLM) procedure using a Poisson distribution to compare means between restored sites. CSIInorm met parametric conditions; we therefore performed an ANOVA. Three pairwise comparisons, with Benjamini-Hochberg adjustment, were carried out: 1) to compare dates of transfer at the 1:3 ratio on the former orchard, 2) to compare autumn transfer ratios on the former orchard and 3) to compare the spring 1:3 transfer on the former 
222 orchard and the spring 1:1 transfer on the pipeline leak site. To determine the combined effect 223 of year (1, 2 and 3 years after transfer), and treatments (ratio-season combination) on 224 CSIInorm we performed two-way ANOVA on repeated measures, followed by Tukey

225

226

227

228

229

230

231

232

233

234

235

236

237

238

239

240

241

242

243

244

245

246

247

248

249

250

251

252

253

254 honestly significant difference post-hoc tests.

All analyses were performed with R software 3.3.2 (R Core Team 2016) and its 'vegan' package (Oksanen et al. 2017).

\section{Results}

\section{Seed bank}

The soil seed bank collected in summer contained more species ( $15.2 \pm 0.6$ species / sample) than that collected in early spring $(5.4 \pm 1.0$ species / sample) $(\mathrm{z}=45.08, \mathrm{p}<0.001$; Figure $2 \mathrm{a})$. The seed bank collected in summer also contained more seeds (101.1 \pm 8.3 seeds / sample) than that collected in early spring $(8.7 \pm 1.8$ seeds / sample $)(z=-852.86, \mathrm{p}<0.001$; Figure $2 \mathrm{~b})$. Although they shared many species, the two seed bank communities were separated along the RDA first axis (Figure 3). Spring samples were differentiated from summer samples by the presence of Sagina apetala, absent from the summer seed bank. The summer seed bank samples were characterized by species like Gastridium ventricosum, Vulpia sp., Aira cupaniana, Catapodium rigidum, Galium parisiense, Bromus hordeaceus and Melica ciliata which were not, or only rarely, found in the spring seed bank. The samples collected in spring were more dispersed on the RDA ordination than those collected in summer. Most of the species found in the spring and summer seed bank were species found in the reference grassland (thus target species), although similarity was below 0.4 for both seasons (Figure 3; $\mathrm{t}=-6.58 ; \mathrm{p}<0.001$ ). Out of the 1089 germinations, we identified 50 species (14 in spring and 38 in summer), only 5 of which were non-target species. Senecio vulgaris (49 germinations), which mainly germinated outside the summer seed bank, is naturally and sporadically found in La Crau grasslands. The other four species, Verbena officinalis (65 germinations, 13 in spring and 52 in summer), Kickxia elatine (3 germinations, 1 in spring and 2 in summer) Chenopodium album (2 germinations, 1 in spring and 1 in summer) and Portulaca oleracea ( 2 germinations in spring) were not found in the above-ground grassland vegetation; they are arable weeds dispersed from formerly irrigated fields found around the study site (Römermann et al. 2005; Buisson et al. 2006).

\section{Topsoil transfers}


255 The year following topsoil transfer, species richness $(z=106.59 ; \mathrm{p}<0.001)$ and similarity to 256 the reference site (CSIInorm; $F=14.35$; $\mathrm{p}<0.001)$ significantly differed between treatments 257 (ratio-season combination): both these variables were higher for spring soil transfer than for 258 autumn soil transfer on the former orchard (see results of post-hoc tests, Figure 4).

259 Moreover, for the spring transfers, similarity to the reference site was slightly significantly 260 higher with the 1:1 transfer ratio on the pipeline leak site than with the 1:3 transfer ratio on 261 the former orchard (Figure 4). Transfer ratios did not affect species richness and similarity to 262 the reference site for the former orchard. In spring, similarity was higher for the pipeline leak 263 site transfer at a ratio of 1:1 than for the former orchard transfer at a ratio of 1:3 (Figure 4). 264 Overall, the plant compositions of the different topsoil transfers were rather similar, with 265 many species characteristic of the reference grassland such as Carlina corymbosa, Thymus 266 vulgaris or Trifolium stellatum (Figure 5). However the topsoil transferred onto the pipeline 267 leak site had a slightly different plant composition characterized by ruderal species like 268 Cardamine hirsuta or Lolium perenne. The topsoil transferred onto the former orchard was 269 characterized by ruderal species like Bromus diandrus, Chenopodium album, Hirschfeldia 270 incana and Lactuca serriola (Figure 5).

271 From the second year after transfers, only the spring pipeline leak site transfer at a 272 ratio of 1:1 retained high similarity to the reference site, above $80 \%$. For all transfers 273 implemented at the former orchard site, regardless of transfer season or ratio, similarity 274 dropped to below 60\% (Figure 6). 


\section{Discussion}

276 Topsoil transfer timing

277 The La Crau Mediterranean dry grassland has a mainly transient seed bank (Buisson et al.

278 2006). Since most of the plants are annuals and spend the harsh season (summer) as seeds in 279 the seed bank, the most advantageous season for topsoil transfer should clearly be summer.

280 Moreover, seeds can be expected to germinate in autumn: in a Mediterranean climate, not 281 only is germination triggered by temperature and light, but it also occurs only after a 282 threshold amount of precipitation (Ne'eman \& Goubitz 2000). Differences cannot simply be 283 explained by dormancy cycles, as germination of annual Mediterranean species depends on 284 the timing and amount of autumn precipitation (Espigares \& Peco 1993, 1995). The results of 285 our seed bank study support our first hypothesis, showing that species richness and seed 286 density and similarity of species composition between seed bank and above-ground 287 vegetation of the reference site are much higher in the summer than in the spring seed bank. 288 The latter is more dispersed on the community ordination because only a few seeds 289 germinated in each spring sample (Römermann et al. 2005), giving each species a higher 290 weight than the species composing the more abundant summer seed bank community.

While summer appears to be the most appropriate season for transferring the seed 292 bank, restoration work cannot always be implemented when it would be ideal in terms of 293 resilience of the restored plant community. This is mainly due to constraints inherent to 294 worksites and because restoration planning usually takes into account not only the phenology 295 of plant communities but also that of endangered plant species and of animals, such as 296 nesting birds (Buisson et al. 2017). Thus, topsoil transfer was never implemented in summer to restore our Mediterranean dry grassland.

\section{Season for Mediterranean dry grassland topsoil transfer}

300 Topsoil transfer was not carried out in summer on the Mediterranean grassland due to site 301 preparation delays (soil levelling on the former orchard and polluted soil excavation on the 302 pipeline leak site; see Jaunatre et al. 2014a; Bulot et al. 2014; 2017 for details). As many 303 annual species germinate with the first autumn rains, it was difficult to hypothesize that either 304 autumn or spring would be the best transfer season. In the first year, spring topsoil transfer 305 led to high species richness on the restoration site and high similarity with the reference site 306 (ca. 80\%) compared to autumn transfer (slightly over $40 \%$ ). This may be partly due to the 307 fact that a few species, such as Bellis sylvestris, Lobularia maritima, flower and produce 
seeds mainly in autumn and are thus added to the pool of potentially germinable species in spring. In this study, these two species germinated with both transfers but their frequency of occurrence was higher on the restoration sites where spring topsoil transfers were performed. We observed annual Fabaceae common in the reference grassland, such as Medicago minima, Medicago monspeliaca, Medicago truncatula, Trifolium cherleri, Trifolium scabrum and Trifolium stellatum, more frequently with the spring than with the autumn transfers. Van Assche et al. (2003) showed that some species congeneric to those cited here show increased germination efficiency with cold stratification. They would therefore germinate better after winter, explaining the results from spring transfers in our study. Surprisingly, numerous annual species known through seedling emergence studies to have a transient seed bank and accordingly not found in our spring seed bank study, were found under spring soil transfer. This may partly be due to the fact that species with low seed production and species whose germination requirements are narrow are less likely to be detected by seed bank studies (Saatkamp et al. 2009). Moreover, species whose seeds massively germinate with autumn rain are hard to detect in spring. It can thus be expected that a wider range of species will establish from spring topsoil transfer than predicted from seed bank studies (Kalamees \& Zobel 2002). Here, the restoration following polluted soil excavation on the pipeline leak site, which involved a spring transfer of 41000 tons of soil, gave better results than predicted via seed bank studies on a few kilos of soil (Bulot et al. 2014).

Perennial species of this Mediterranean dry grassland do produce seeds that can germinate in autumn in the field and form a seed bank (e.g. Dactylis glomerata; 64 germinations in the summer seed bank vs. 14 in the spring seed bank / 1089 germinations). Perennial plants also make it through summer drought thanks to the survival of the organs (meristematic tissues at the bases of leaves, roots, underground storage organs) from which they regrow once water is available (Volaire et al. 2009; Moreira et al. 2012). They store carbohydrates during the growing season, before the onset of drought, which allows them to maintain respiration demands during summer and to initiate resprouting (Volaire et al. 2009; Moreira et al. 2012). Thus, topsoil transfer in autumn may not have given them enough time to replenish their reserves to be resilient to a second stressful situation, such as translocation: Brachypodium retusum established better in spring than in autumn, as did Cynodon dactylon and Bothriochloa ischaemum, though to a lesser extent. An attempt to translocate perennial species in summer would show whether experiencing two simultaneous disturbances (drought 
341 and translocation), rather than one occurring after the other, provides a better chance of survival.

Differences between restored grassland sites

345 Topsoil transfer on the pipeline leak site yielded few ruderal species, and even those were ruderal species also found on the reference grassland, such as Cardamine hirsuta or Lolium perenne. Contrastingly, topsoil transfer on the former orchard led to communities dominated by ruderal species like Bromus diandrus, Chenopodium album and Hirschfeldia incana, absent from the reference grassland but common on the rehabilitated areas of the former orchard where topsoil transfer was not performed (Jaunatre et al 2014a). This major difference between the two restored sites is due to a difference in restoration process: on the pipeline leak site, the soil horizons were entirely reconstituted, while on the former orchard, topsoil was spread on top of orchard soil containing its own seed bank of weeds (Jaunatre et al 2014a). It is likely that the different restoration processes also largely explain the differences between transfer ratios in spring: the 1:1 ratio soil transfer implemented on the pipeline leak site produced results more similar to the reference one year after transfer than the 1:3 ratio soil transfer implemented on the former orchard.

Autumn soil transfer ratios on the former orchard did not affect species richness and similarity to the reference one year after transfer. The representation on the ordination of the autumn 1:3 transfer ratio on the former orchard is more dispersed, most probably due to the greater sampling effort.

In subsequent years, $80 \%$ similarity to the reference site was maintained with the spring 1:1 ratio topsoil transfer on the pipeline leak site, whereas the spring 1:3 ratio topsoil transfer on the former orchard led to similarity falling to below $50 \%$. There are two possible explanations. First, the 1:3 ratio does not transfer enough seeds for the community to be maintained long-term. However, this is contradicted by the fact that similarity with the reference is identical with both ratios for the autumn transfers. The second likely explanation is the differences between sites and restoration processes. The seed bank and soil nutrient content are affected by cultivation legacy, and there can be long-term effects on plant communities (Cramer et al. 2008; Smits et al. 2008). On the former orchard, weed seed load in the seed bank and nutrients in the soil are therefore greater, resulting in high average vegetation height and cover (Jaunatre et al 2014a). This may have had a negative effect on 
373 the germination and growth of less competitive light-demanding grassland target species

374 (Hautier et al. 2009).

375

376

Seed bank studies help acquire a better understanding of ecosystem functioning and 377 thus help restorationists plan better transfer timing. However, they do not provide a clear

378

379

380

381

382

383

384

385

386

387

388

389

390

391

392

393

394

395

396

397

398

399

400

401

402

403

404

405 prediction of restoration success, since they largely underestimate the true seed density in the seed bank due to detection probabilities, dormancy and germination niches (De Villiers et al. 2004; Fowler et al. 2005). The outcome for bulk soil transfers in Mediterranean ecosystem restoration depends on several factors: transferred soil depth, whether the soil is stockpiled and whether soil horizons are reconstituted (Koch 2007; Coiffait-Gombault et al. 2011; Bulot et al. 2014), the proportion of annual species in the donor site seed bank, and the fertility and seed bank of the receptor site (Jaunatre et al 2014a; Fowler et al. 2015). Restoration success is also highly dependent on appropriate scheduling of the various tasks, although in practice timing is also governed by worksite imperatives. More importantly, restoration implies taking into account a set of environmental parameters not at play in seed bank studies. The patterns of some of these parameters can partly be foreseen on worksites (e.g. sites scheduled for restoration may be colonized by arable weeds germinating from the seed bank dating back to former agricultural activities; Buisson et al. 2006; Jaunatre et al. 2014a). However, this does not necessarily mean that they can be dealt with in advance. Ecological restoration will therefore partly remain a trial and error process and restored sites will require subsequent adaptive management.

\section{Acknowledgments}

This study was supported by CDC Biodiversité, the Conseil Régional de Provence Alpes Côtes d'Azur and CNRS RTP Ingecotech funding. We are also grateful to CEN PACA Ecomusée de Crau, Réserve Naturelle des Coussouls de Crau, and Société des Carrières de La Ménudelle for their collaboration. The authors would like to thank M. Sweetko for reviewing the English, and N. Hölzel and an anonymous reviewer, as well as Coordinating Editor A. Helm, for improving previous versions.

(1)

\section{References}


Bakker JP, Bakker ES, Rosén E, Verweij GL, Bekker RM (1996) Soil seed bank composition along a gradient from dry alvar grassland to Juniperus shrubland. Journal of Vegetation Science 7:165-176

Bossuyt B, Honnay O (2008) Can the seed bank be used for ecological restoration? An overview of seed bank characteristics in European communities. Journal of Vegetation Science 19:875-884

Braun-Blanquet J, Roussine N, Nègre R (1952) Les groupements végétaux de la France méditerranéenne. CNRS. Paris, France

Buisson E, Alvarado ST, Le Stradic S, Morellato LPC (2017) Plant phenological research enhances ecological restoration. Restoration Ecology 25:164-171

Buisson E, Dutoit T (2006) Creation of the natural reserve of La Crau: Implications for the creation and management of protected areas. Journal of Environmental Management $80: 318-326$

Buisson E et al. Buisson E, Dutoit T, Torre F, Römermann C, Poschlod P (2006) The implications of seed rain and seed bank patterns for plant succession at the edges of abandoned fields in Mediterranean landscapes. Agriculture, Ecosystems \& Environment 115:6-14

Bullock JM (1998) Community translocation in Britain: Setting objectives and measuring consequences. Biological Conservation 84:199-214

Bulot A, Potard K, Bureau F, Bérard A, Dutoit T (2017) Ecological restoration by soil transfer: impacts on restored soil profiles and topsoil functions. Restoration Ecology $25: 354-366$

Bulot A, Provost E, Dutoit T (2014) comparison of different soil transfer strategies for restoring a Mediterranean steppe after a pipeline leak (La Crau plain, South-Eastern France). Ecological Engineering 71:690-702

Coiffait-Gombault C, Buisson E, Dutoit T (2011) Hay transfer promotes establishment of Mediterranean steppe vegetation on soil disturbed by pipeline construction. Restoration Ecology 19:214-222

Cramer V, Hobbs R, Standish R (2008) What's new about old fields? Land abandonment and ecosystem assembly. Trends in Ecology \& Evolution 23:104-112

De Villiers AJ, Van Rooyen MW, Theron GK, Cowling RM (2004) The restoration of Strandveld and Succulent Karoo degraded by mining: an enumeration of topsoil seed banks. South African Journal of Botany 70:717-725 
Dutoit T, Jaunatre R, Buisson E (2013) Mediterranean steppe restoration in France. In: Ecological Restoration, Second Edition: Principles, Values, and Structure of an Emerging Profession. Clewell AF, Aronson J (eds) p. 60

Espigares T, Peco B (1993) Mediterranean pasture dynamics: the role of germination. Journal of Vegetation Science 4:189-194

Espigares T, Peco B (1995) Mediterranean annual pasture dynamics: impact of autumn drought. Journal of Ecology 83:135-142

Fowler WM, Fontaine JB, Enright NJ, Veber WP (2015) Evaluating restoration potential of transferred topsoil. Applied Vegetation Science 18:379-390

Good JEG, Wallace HL, Stevens PA, Radford GL (1999) Translocation of herb-rich grassland from a site in Wales prior to opencast coal extraction. Restoration Ecology $7: 336-347$

Grillas P, Gauthier P, Yavercovski N, Perennou C (2004) Les mares temporaires méditerranéennes: enjeux de conservation, fonctionnement et gestion vol1. Station biologique de la Tour du Valat, Arles

Grman E, Bassett T, Zirbel CR, Brudvig LA (2015) Dispersal and establishment filters influence the assembly of restored prairie plant communities. Restoration Ecology 23:892-899

Halassy M, Singh AN, Szabó R, Szili-Kovács T, Szitár K, Török K (2016) The application of a filter-based assembly model to develop best practices for Pannonian sand grassland restoration. Journal of Applied Ecology 53:765-773

Hautier Y, Niklaus PA, Hector A (2009) Competition for light causes plant biodiversity loss after eutrophication. Science 324:636-638

Hosogi D, Kameyama A (2004) Timing for the collection of topsoil from a deciduous forest for use as planting material in suburban Tokyo, Japan. Ecological Engineering 23:371386

Jaunatre R, Buisson E, Muller I, Morlon H, Mesléard F, Dutoit T (2013) New synthetic indicators to assess community resilience and restoration success. Ecological Indicators 29:468-477

Jaunatre R, Buisson E, Coiffait-Gombault C, Bulot A, Dutoit T (2014b) Restoring speciesrich Mediterranean dry grassland in France using different species-transfer methods. In: Guidelines for Native Seed Production and Grassland Restoration. Kiehl K, Kirmer A, Shaw N (eds), Cambridge, UK pp. 182-197. 
472 Jaunatre R, Buisson E, Dutoit T (2014a) Can ecological engineering restore Mediterranean

473

474

475

476

477

478

479

480

481

482

483

484

485

486

487

488

489

490

491

492

493

494

495

496

497

498

499

500

501

502

503 rangeland after intensive cultivation? A large-scale experiment in southern France. Ecological Engineering 64:202-212

Kalamees R, Zobel M (2002) The role of the seed bank in gap regeneration in a calcareous grassland community. Ecology 83:1017-1025

Kalamees R, Püssa K, Zobel K, Zobel M (2012) Restoration potential of the persistent soil seed bank in successional calcareous (alvar) grasslands in Estonia. Applied Vegetation Science 15:208-218

Kardol P, Bezemer TM, Van Der Putten WH (2009) Soil organism and plant introductions in restoration of species-rich grassland communities. Restoration Ecology 17:258-269

Kiehl K, Kirmer A, Donath TW, Rasran L, Hölzel N (2010) Species introduction in restoration projects - Evaluation of different techniques for the establishment of seminatural grasslands in Central and Northwestern Europe. Basic and Applied Ecology 11:285-299

Koch JM (2007) Alcoa's mining and restoration process in South Western Australia. Restoration Ecology 15:S11-S16

Legendre P, Gallagher ED (2001) Ecologically meaningful transformations for ordination of species data. Oecologia 129:271-280

Moreira B, Tormo J, Pausas JG (2012) To resprout or not to resprout: factors driving intraspecific variability in resprouting. Oikos 121:1577-1584

Ne'eman G, Goubitz S (2000) Phenology of east-Mediterranean vegetation. In: Life and environment in the Mediterranean, WIT Press. Trabaud, L., pp 155-202

Oksanen J, Blanchet FG, Friendly M, Kindt R, Legendre P, Minchin PR, et al (2017) Package 'vegan'.

R Core Team (2016) R: A Language and Environment for Statistical Computing. R Foundation for Statistical Computing, Vienna, Austria

Römermann C, Dutoit T, Poschlod P, Buisson E (2005) Influence of former cultivation on the unique Mediterranean steppe of France and consequences for conservation management. Biological Conservation 121:21-33

Saatkamp A, Affre L, Dutoit T, Poschlod P (2009) The seed bank longevity index revisited: limited reliability evident from a burial experiment and database analyses. Annals of Botany 104:715-724 
504 Smits NAC, Willems JH, Bobbink R (2008) Long-term after-effects of fertilisation on the 505 restoration of calcareous grasslands. Applied Vegetation Science 11:279-286

506 Ter Heerdt GNJ, Verweij GL, Bekker RM, Bakker JP (1996) An improved method for seed-

507 bank analysis: seedling emergence after removing the soil by sieving. Functional

$508 \quad$ Ecology 10:144-151

509 Török P, Vida E, Deák B, Lengyel S, Tóthmérész B (2011) Grassland restoration on former

510 croplands in Europe: an assessment of applicability of techniques and costs.

511 Biodiversity and Conservation 20:2311-2332

512 Van Assche JA, Debucquoy KLA, Rommens WAF (2003) Seasonal cycles in the 513 germination capacity of buried seeds of some Leguminosae (Fabaceae). New $514 \quad$ Phytologist 158:315-323

515 Vécrin MP, Muller S (2003) Top-soil translocation as a technique in the re-creation of 516 species-rich meadows. Applied Vegetation Science 6:271-278

517 Volaire F, Norton MR, Lelièvre F (2009) Summer drought survival strategies and 518 sustainability of perennial temperate forage grasses in Mediterranean areas. Crop $519 \quad$ Science 49:2386

520 Wubs ERJ, Putten WH van der, Bosch M, Bezemer TM (2016) Soil inoculation steers restoration of terrestrial ecosystems. Nature Plants 2:16107 
Table 1. Dry grassland seed bank study and topsoil transfer details, showing protocols as well as subsequent vegetation monitoring. FO stands for former orchard and PL for

\begin{tabular}{|c|c|c|c|c|}
\hline & $\begin{array}{c}\text { reference } \\
\text { vegetation }\end{array}$ & $\begin{array}{c}\text { seed bank and } \\
\text { season }\end{array}$ & $\begin{array}{c}\text { topsoil transfer } \\
\text { monitoring }\end{array}$ & objectives \\
\hline sites & $\begin{array}{l}3 \text { sites of dry } \\
\text { grassland }\end{array}$ & $\begin{array}{c}1 \text { site of dry } \\
\text { grassland (Peau } \\
\text { de Meau; } \\
43^{\circ} 34^{\prime} 01.85^{\prime \prime N} \\
\left.4^{\circ} 50^{\prime} 07.12^{\prime \prime} \mathrm{E}\right)\end{array}$ & $\begin{array}{c}2 \text { sites }(\mathrm{FO}, \mathrm{PL}), \text { see } \\
\text { Table } 1 \text { for details }\end{array}$ & $\begin{array}{l}\text { to determine } \\
\text { the best time } \\
\text { to transfer } \\
\text { topsoil in } \\
\text { Mediterranean } \\
\text { grasslands }\end{array}$ \\
\hline \multirow{4}{*}{ monitoring } & \multirow{3}{*}{$6 \times 4 \mathrm{~m}^{2}$ plots / site } & \multirow{3}{*}{$\begin{array}{c}\text { Seed bank: } 10 \\
\text { 2.5-L samples } \\
\text { (pooled } \\
\text { subsamples) } \\
\text { taken between } 0 \\
\text { and } 20 \mathrm{~cm} \text { deep, } \\
2 \text { seasons (April, } \\
\text { August) } \\
\text { Vegetation: } 10 \times \\
4 \mathrm{~m}^{2} \text { plots }\end{array}$} & $\begin{array}{l}\text { Aut. 1:1 - FO: transfer } \\
\text { from Ménudelle } 1: 1 \text { ( } 3 \\
\times 0.1 \text { ha) in autumn: } \\
\text { three } 4-\mathrm{m}^{2} \text { plots } \\
\text { Aut. } 1: 3 \text { - FO: transfer } \\
\text { from Ménudelle } 1: 3 \text { (3 } \\
\quad \times 1 \text { ha) in autumn: } \\
\text { eighteen } 4-\mathrm{m}^{2} \text { plots }\end{array}$ & \multirow{4}{*}{$\begin{array}{l}\text { to determine } \\
\text { the best topsoil } \\
\text { transfer } \\
\text { treatment } \\
\text { (ratio-season } \\
\text { combination) }\end{array}$} \\
\hline & & & $\begin{array}{c}\text { Spring 1:3 - FO: } \\
\text { transfer from Massilia } \\
\text { 1:3 }(1 \times 1 \text { ha }) \text { in } \\
\text { spring: three } 4-\mathrm{m}^{2} \\
\text { plots }\end{array}$ & \\
\hline & & & $\begin{array}{c}\text { Spring 1:1 - PL }(1 \times \\
5.5 \text { ha) in spring: nine } \\
\text { 4- } \mathrm{m}^{2} \text { plots }\end{array}$ & \\
\hline & $\begin{array}{c}\text { vegetation } \\
\text { sampling, } \mathrm{BB} \\
\text { index (total }=18 \\
\text { plots) }\end{array}$ & $\begin{array}{l}\text { germination } \\
\text { identification } \\
\text { and count, } \\
\text { vegetation } \\
\text { sampling } \\
\text { (presence / } \\
\text { absence) }\end{array}$ & $\begin{array}{l}\text { vegetation sampling, } \\
\text { BB index }\end{array}$ & \\
\hline references & $\begin{array}{l}\text { Jaunatre et al. } \\
2014 \mathrm{a}\end{array}$ & $\begin{array}{l}\text { Römermann et } \\
\text { al. } 2005 \text { and } \\
\text { unpublished }\end{array}$ & $\begin{array}{c}\text { Jaunatre et al. } \\
\text { 2014a,b; Bulot et al. } \\
2017 \text { and unpublished }\end{array}$ & \\
\hline
\end{tabular}
pipeline leak site. 
Table 2. Topsoil transfer data used to determine the best topsoil transfer treatment (ratio-season combination). Coordinates of and distance between donor and restored (receptor) sites. Area covered (ha), ratio and season are indicated for each transfer.

\begin{tabular}{|c|c|c|c|c|c|c|c|c|}
\hline $\begin{array}{l}\text { donor } \\
\text { sites }\end{array}$ & coordinates & $\begin{array}{l}\text { restored (receptor) } \\
\text { sites }\end{array}$ & coordinates & $\begin{array}{l}\text { distance }(\mathbf{k m}) \\
\text { between donor } \\
\text { and restored } \\
\text { sites }\end{array}$ & $\begin{array}{c}\text { Surface area } \\
\text { (ha) covered } \\
\text { by topsoil } \\
\text { transfer }\end{array}$ & ratio & season & month \\
\hline Massilia & $\begin{array}{l}43^{\circ} 29^{\prime} 03.61^{\prime \prime N} \\
4^{\circ} 53^{\prime} 16.56^{\prime \prime} \mathrm{E}\end{array}$ & \multirow{3}{*}{ Former orchard } & \multirow{3}{*}{$\begin{array}{c}43^{\circ} 31^{\prime} 07.38^{\prime \prime N} \\
4^{\circ} 51^{\prime} 35.05^{\prime \prime} \mathrm{E}\end{array}$} & \multirow{3}{*}{3.5} & $1 \times 1$ ha & $1: 3$ & spring & $\begin{array}{l}\text { March } \\
2009\end{array}$ \\
\hline \multirow{3}{*}{$\begin{array}{c}\text { Ménudell } \\
\text { e }\end{array}$} & \multirow{3}{*}{$\begin{array}{l}43^{\circ} 30^{\prime} 30.22^{\prime \prime} \mathrm{N} \\
4^{\circ} 54^{\prime} 03.14^{\prime \prime} \mathrm{E}\end{array}$} & & & & $3 \times 1$ ha & $1: 3$ & $\begin{array}{c}\text { autum } \\
\mathrm{n}\end{array}$ & Oct. 2009 \\
\hline & & & & & $3 \times 0.1$ ha & $1: 1$ & $\begin{array}{c}\text { autum } \\
\mathrm{n}\end{array}$ & Oct. 2009 \\
\hline & & Pipeline leak site & $\begin{array}{c}43^{\circ} 31^{\prime} 36.77^{\prime \prime} \mathrm{N} \\
4^{\circ} 53^{\prime} 04.50^{\prime \prime} \mathrm{E}\end{array}$ & 2.5 & $1 \times 5.5 \mathrm{ha}$ & $1: 1$ & spring & $\begin{array}{c}\text { March- } \\
\text { April } 2011\end{array}$ \\
\hline
\end{tabular}


Figure 1. Map of the donor and restored (receptor) sites and as well as of the seed bank study site. $\mathrm{FO}=$ former orchard and $\mathrm{PL}=$ pipeline leak site where dry grassland topsoil transfers were implemented. See Table 1 for details.

Figure 2. a. Species richness, b. seed density density and c. normalized Community structure Integrity Index of the soil seed bank of Peau de Meau, Mediterranean dry grassland (reference grassland), at two seasons (spring: early spring and summer: end of summer).

Figure 3. Soil seed bank ordination of samples from Peau de Meau, Mediterranean dry grassland (reference grassland) gathered at two seasons (spring: early spring and summer: end of summer) based on RDA of plant community composition. For clarity, only the 16 most correlated species are shown (out of 38).

Figure 4. a. Species richness of the areas restored using topsoil transfers from Mediterranean dry grassland and; b. CSIInorm, normalized Community Structure Integrity Index with reference grassland vegetation monitoring as reference compared with restored communities. Soil gathering season (spring in pink; Aut.: autumn in green), transfer ratio (1:3 light colors; 1:1 dark colors) and receptor sites (Former Orchard; Pipeline Leak site). Error bars represent $\pm \mathrm{SE}$, horizontal bars represent pairwise comparisons (NS: $\mathrm{p}>0.05 ; *: \mathrm{p}<0.05 ; * * *: \mathrm{p}<0.001)$.

Figure 5. Plant community ordination one year after different topsoil transfers from Mediterranean dry grassland for different soil gathering seasons (spring in pink; autumn in green), transfer ratios (1:3 light colors; 1:1 dark colors) and receptor sites (Former Orchard; Pipeline Leak site) based on NMDS of plant community composition, final stress $=0.16$. For clarity, only the 19 most correlated species are shown (out of 99).

Figure 6. CSIInorm, normalized Community Structure Integrity Index with reference grassland vegetation monitoring as reference compared with communities restored using topsoil transfers from Mediterranean dry grassland and interactions with years (1 to 3 years after transfers, from dark to light shades). Soil gathering seasons 
(spring in pink; autumn in green), transfer ratios (1:3 light colors; 1:1 dark colors) and receptor sites (Former Orchard; Pipeline Leak site). Error bars represent \pm SE, bars having a common letter are not significantly different (Tukey honest significant differences post-hoc tests after ANOVA on repeated measures; $p>0.05$ ). 
Figure 1.

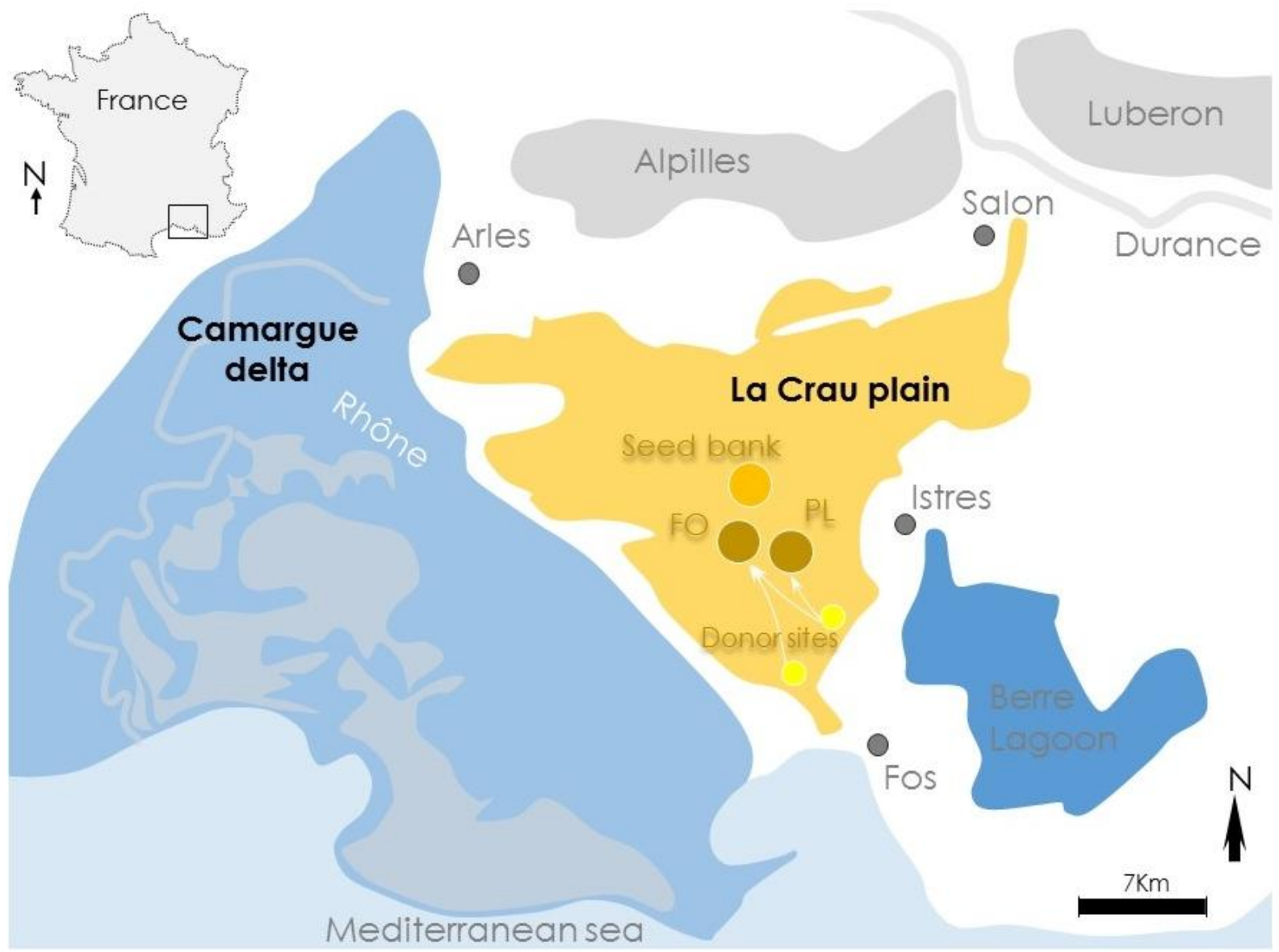

Figure 1. Map of the donor and restored (receptor) sites and as well as of the seed bank study site. $\mathrm{FO}=$ former orchard and $\mathrm{PL}=$ pipeline leak site where dry grassland topsoil transfers were implemented. See Table 1 for details. 
Figure 2.
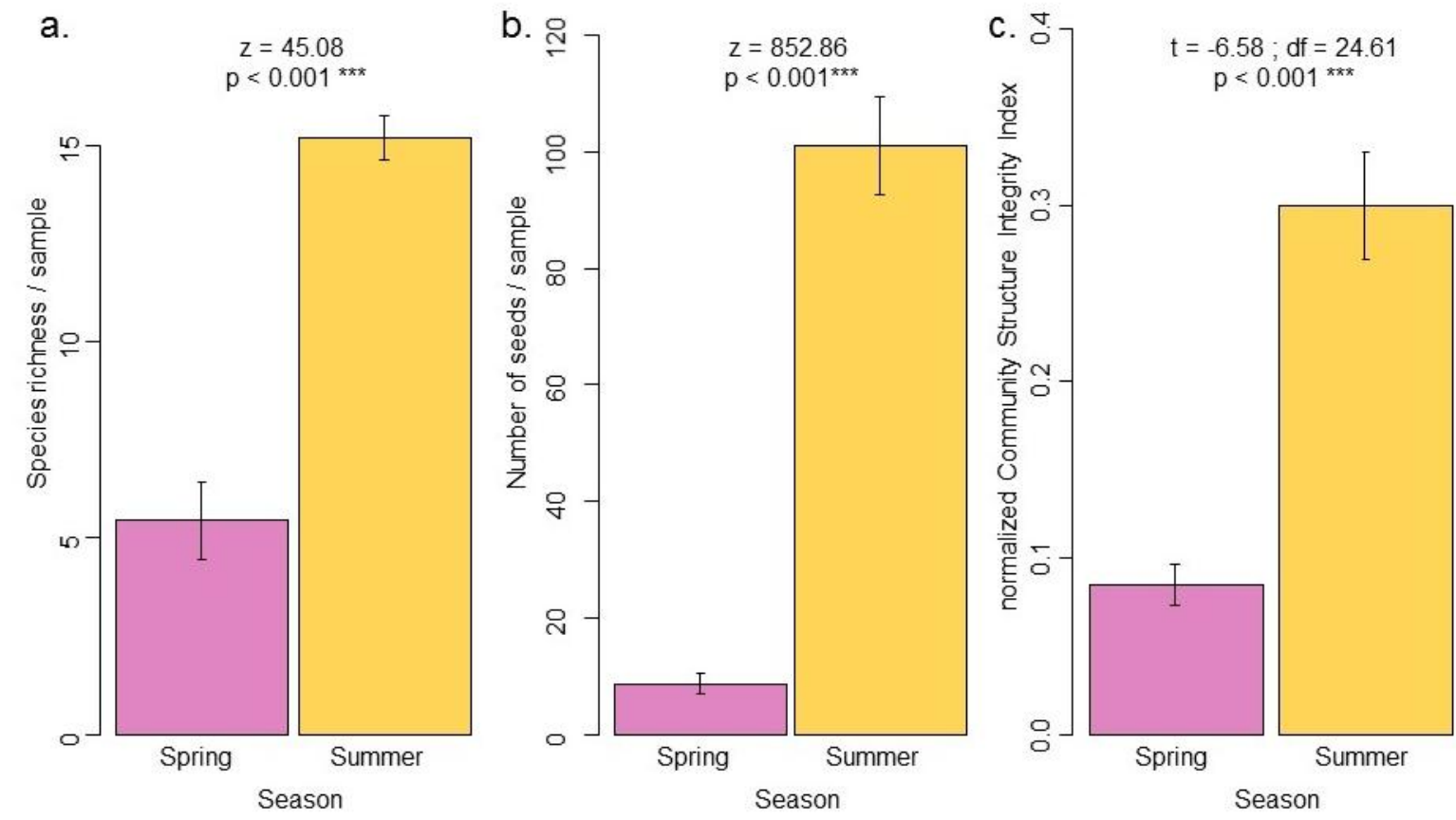

Figure 2. a. Species richness, b. seed density and c. normalized Community structure Integrity Index of the soil seed bank of Peau de Meau, Mediterranean dry grassland (reference grassland), at two seasons (spring: early spring in pink and summer: end of summer in yellow). Error bars represent \pm SE. 
Figure 3.

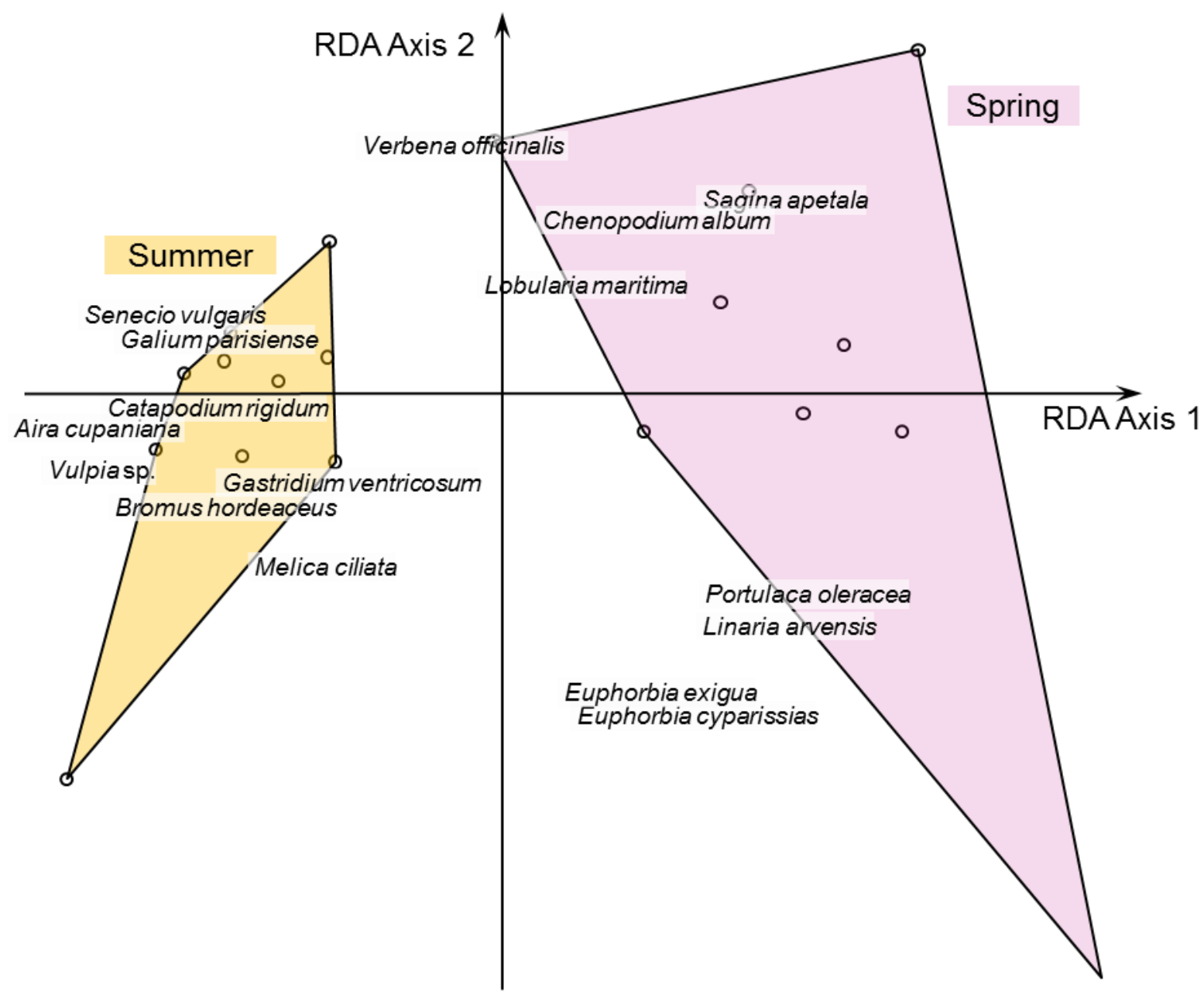

Figure 3. Soil seed bank ordination of samples from Peau de Meau, Mediterranean dry grassland (reference grassland) gathered at two seasons (spring: early spring in pink and summer: end of summer in yellow) based on RDA of plant community composition. For clarity, only the 16 most correlated species are shown (out of 38). 
Figure 4.
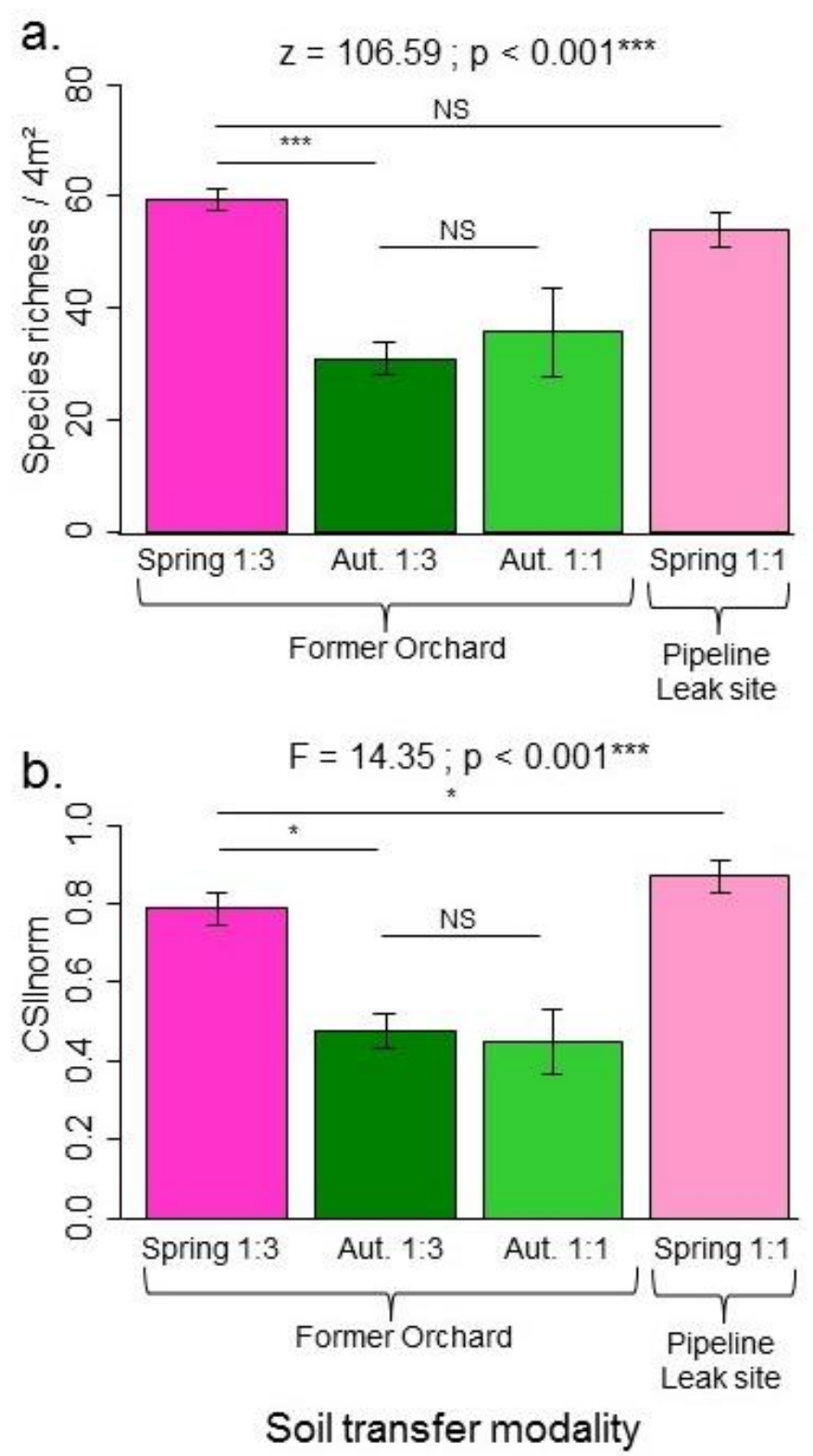

Figure 4. a. Species richness of the areas restored using topsoil transfers from Mediterranean dry grassland and; b. CSIInorm, normalized Community Structure Integrity Index with reference grassland vegetation monitoring as reference compared with restored communities. Soil gathering seasons (spring in pink; Aut.: autumn in green), transfer ratios (1:3 light colors; 1:1 dark colors) and receptor sites (Former Orchard; Pipeline Leak site). Error bars represent \pm SE, horizontal bars represent pairwise comparisons (NS: $\mathrm{p}>0.05 ; *: \mathrm{p}<0.05 ; * * *: \mathrm{p}<0.001)$. 
Figure 5.

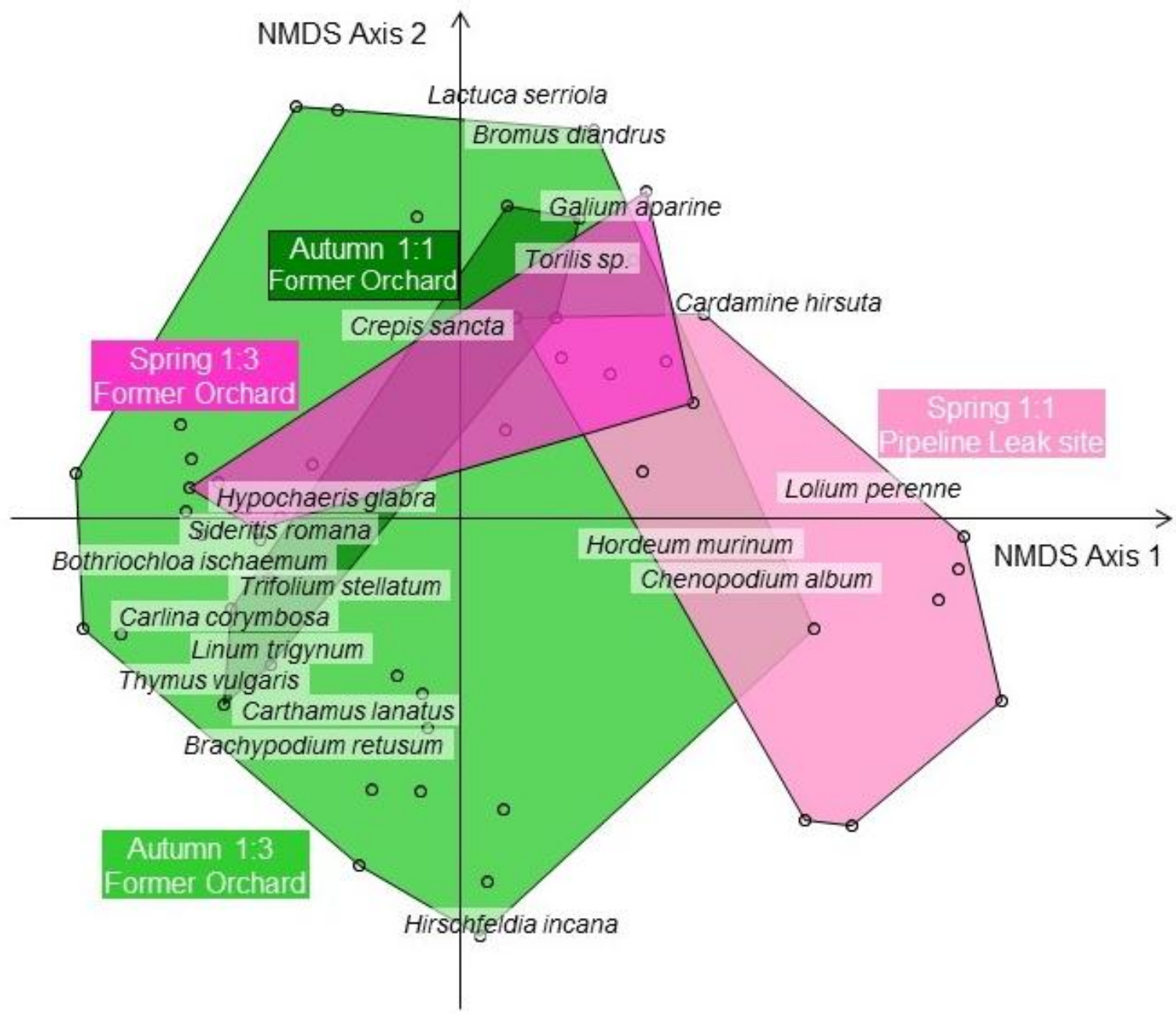

Figure 5. Plant community ordination one year after different topsoil transfers from Mediterranean dry grassland for different soil gathering seasons (spring in pink; autumn in green), transfer ratios (1:3 light colors; 1:1 dark colors) and receptor sites (Former Orchard; Pipeline Leak site) based on NMDS of plant community composition, final stress $=0.16$. For clarity, only the 19 most correlated species are shown (out of 99). 
Figure 6.

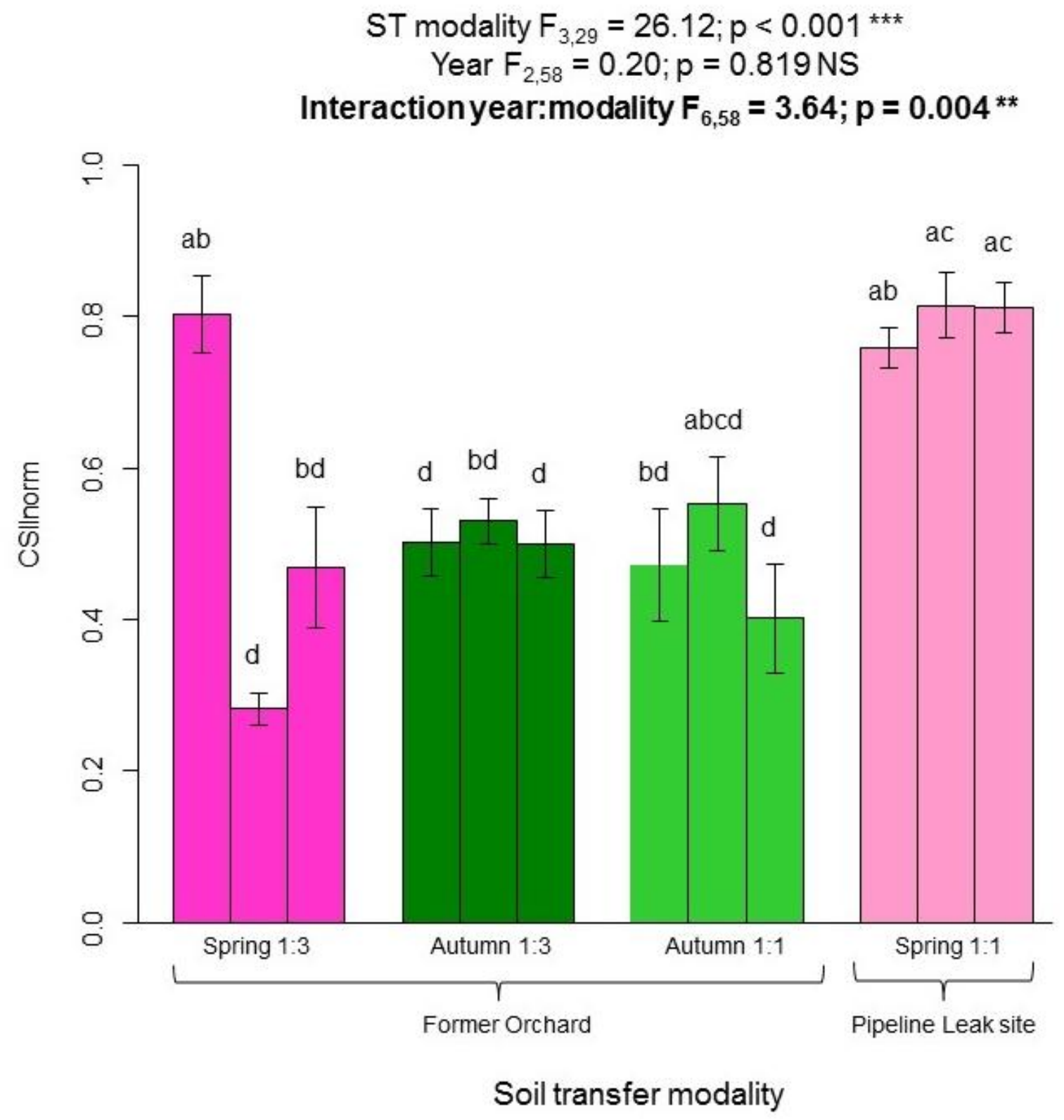

Figure 6. CSIInorm, normalized Community Structure Integrity Index with reference grassland vegetation monitoring as reference compared with communities restored using topsoil transfers from Mediterranean dry grassland and interactions with years (1 to 3 years after transfers, from dark to light shades). Soil gathering seasons (spring in pink; autumn in green), transfer ratios (1:3 light colors; 1:1 dark colors) and receptor sites (Former Orchard; Pipeline Leak site). Error bars represent $\pm \mathrm{SE}$, bars having a common letter are not significantly different (Tukey honest significant differences post-hoc tests after ANOVA on repeated measures; $p>0.05$ ). 